\title{
Geographic and Product Diversification Facilitating an Improper Distribution of Wealth
}

\author{
José G. Vargas-Hernández \\ María del Rocío Sánchez Rico \\ University Center for Economic and Managerial Sciences \\ University of Guadalajara, Periférico Norte N 799, Edif G201-7 \\ Núcleo Universitario Los Belenes, C.P. 45100, Zapopan, Jalisco, México
}

\section{Doi:10.5901/mjss.2013.v4n16p111}

\begin{abstract}
This paper is aimed to show evidence about unbalanced wealth distribution in Mexico, affording more information, knowledge and sensitivity from citizens and Mexican government on behalf of looking for an equitable economic development and increasing the national welfare are the objective from this investigation. Across the assumption: "The growth of FEMSA from geographical and product diversification cannot be considered as a directly proportional indicator to the increase personal and economic welfare of their workers". Was used a qualitative methodology, running an indicators analysis and FEMSA's workers and former workers interviews. The result was that the assumption is correct being relevant and necessary to generate measures allowing a balanced wealth distribution and a real growth of national economy.
\end{abstract}

Keywords: Geographical diversification, product diversification, wealth distribution.

\section{Introduction}

Despite the great diversity of natural resources and the potential to be a country with a strong economy, is a fact that Mexico has been dwindling. There are economic indicators such as the gross domestic product (GDP) apparently showing good results and positive annual growth in the country. However, if it is checked out the quality of life of the population, the reality is that no improvements are identified over time. On the otherwise, the National Consumer Price Index (Índice Nacional de Precios al Consumidor, INPC) as of April 2013 compared to April 2012, has shown an increase of 4.65\%, higher percentage of 2013 against a salary increase for 2013 of $3.9 \%$ before inflation of $4.1 \%$

Mexican companies play a crucial role to bring positive growth to the national economy and by logic correspondence it has improved the quality of life of the population. However, it has been identified major contradictions between these indicators because there are companies that contribute to $9 \%$ national GDP, lower wage increases to inflation and a basic basket at a high price. So there is concern to develop this article in order to show evidence of the unbalanced concentration of wealth in the country, to allow greater information, knowledge and sensitivity of both the citizens and the Mexican government towards the search for strategies to achieve equitable economic development and a real increase of national welfare.

The study is conducted through the analysis of the Mexican company Fomento Economico Mexicano SA (FEMSA) from the perspective of agency theory and External Governance Mechanism "Market for Corporate Control" better known as "Market Mergers and Acquisitions". 


\section{Background of the problem}

Over time, through various research studies focused on market structures, it has been sought the welfare loss associated with the presence of monopoly power (Young, 1996), where one of the dimensions of the dynamic problem is the degree of monopoly entry barriers (Young, 1996). The results that have been generated determine that is potentially significant the welfare loss due to monopoly.

On the other hand, vertical acquisitions, which are the main external governance mechanism, better known as Takeover Market or Market Mergers and Acquisitions (Peng, 2010) have been considered as one of the first choices for growth firms, even studies have shown that firms with either resource constraint to generate innovation and development or to implement their innovations and new developments, are favored with vertical acquisitions, since the firms that have innovation but not have the resources for implementation, integrate with other firms that have the resource for this implementation but which has the restriction of not having innovation and developed required to stay in the market (Brocas, 2002).

Another aspect or situations that may favor the generation of mergers and acquisitions is the failure of internal governance mechanisms, as administrators identify an opportunity to reorder or differently deploy assets of a certain company. They are interested to create a new value and an alternative that is a Vertical Acquisition. Support logic can be identified from the perspective of agency theory (Peng, 2010).

Vertical integration as usual has been considered as a strategy for increasing the welfare of the company (Hamilton and Lee, 1986), though not necessarily so, as indeed may favor to increase market power. However, it is not conducive in reducing transaction costs and improving production technologies (Hamilton and Lee, 1986) and when it comes to the welfare of society, vertical integration favors higher goods and services, damages economy of grassroots and popular sectors, middle class and farmers, businessmen and traders who are in need to purchase raw materials at higher cost (Castañeda and Rodriguez, 2009).

\section{Definition of the problem}

The economic situation is becoming increasingly difficult for the population and is often heard on the news that the expected economic growths are not achieved according to the forecasts estimated by experts. The population on the other hand exposes more frequently than the price of basic goods has grown as ever and increasingly normal goods are acquired with effort, referring it to that of products with price elasticity very close to 0 . The principle of substitution effect is not met in full. Thus, the demand will not decrease substantially. However, to obtain components of the basic basket should be a major release of cash from consumers, who for this article it is referred as consumers, to the Mexican population.

Meanwhile, when it comes to private enterprise, it is continually identified procurement events either horizontal or vertical, foreign direct investment (FDI), private sector participation in the national GDP to 9\%. In short, there is a whole arena where different management teams can compete for the rights of ownership of corporate assets (Peng, 2010).

FEMSA in the Mexican national case, has been gaining increasing market strength through integration strategies that have enabled it to develop a cluster (Peng, 2010), so that has a range of products in the market that do not relate to each other, a strategy that provides competitive advantage and therefore a hierarchy such in the market over time will be of easier acquisition of new firms. However, the apparent success of the Mexican firm FEMSA contradicts the current reality of the Mexican people located across complicated economies.

Thus, there is the research question: Is the growth of FEMSA representing also an improvement in the economic and personal 


\section{Justification}

In general, in view of all, being a worker in a private company of great reputation and excellent positioning, translates to a good quality of life of the worker, a good salary, secured economic stability and also personal stability. In Mexico, the talk of Fomento Economico Mexicano SA (FEMSA) is no exception, because it has FEMSA over time since its inception in 1890, transcending and diversify with particular strategies and cutting edge. Thus, FEMSA has managed to position itself in the Mexican population as one of the major undertaking, successful and also as a good career choice.

However, looking from a different perspective and to have an effect on this, focused specifically on FEMSA, what is the level of reality that exists in the perception of increased intrinsically expected welfare to work in the private sector?

For its part, gross domestic product per capita (GDP) of Mexico has shown positive growth over time (Fondo Monetario Internacional, 2013). However, and generally, for the country, have not been good economic growth expectations, the inflation rate annual increases year after year and it is known that the Mexican country is recognized as one that manages lower wages and salaries around the world (Fondo Monetario Internacional, 2013), in contrast to the National Index of Consumer Prices, showing high prices of the basic basket and with an increasing trend during the first half of 2013 (Instituto Nacional de Estadística y Geografía, 2013).

The growth that FEMSA presents is the result of strategies such as geographical and product diversification, which is strongly recognized as successful, causing the organization to achieve positioning increasingly strengthened. But it sounds incongruous and unreasonable that the welfare of their workers do not improve as the improvement of the organizational situation from the point of view of the business. Thus, it is fully justified the intention to make research relevant to the existence of economic and social well-being of workers and logical same increase reported by FEMSA, expected as a result of excellent performance of each of the operating units that make Fomento Economico Mexicano SA.

\section{Research assumption}

The growth from FEMSA presents strategies such as geographical and product diversification cannot be considered as an effective indicator directly proportional to increase personal and economic welfare of its workers.

\section{Theoretical and conceptual framework}

\subsection{Vertical integration}

Although the concept of mergers and acquisitions is used with some frequency, acquisitions are those that actually run the most. Acquisitions refer to the transfer of control of the assets, operations and management of one firm to another (Peng, 2010), so that the firm is transferred and it becomes an additional unit of the firm that receives the transfer.

There are three main categories of mergers and acquisitions: Horizontal, vertical and conglomerate, where horizontal acquisitions represent those performed by receiving transfer companies before the acquisition was a competitor in the same industry (Peng, 2010). Vertical acquisitions are those that enable firms to acquire either their suppliers, their customers (Peng, 2010) or allowing them to expand their operations through the implementation of activities traditionally undertaken by suppliers or distributors and finally, the clusters that are defined as transactions between firms belonging to unrelated products industries (Peng, 2010).

The vertical acquisitions are one of the first strategies that companies consider for the advancement of 
their firms (Patlán and Navarrete, 2009) and that could strategically gain allies equally efficient and competitive as any organization (Hamilton, 2003). Therefore, it becomes a competitive advantage for companies. It also represents a strategy to increase or decrease the level of control over the inputs and outputs level of the firm (Patlán and Navarrete, 2009).

Among the advantages of vertical acquisitions there is a decrease in transaction costs, ease of obtaining supplies, improve coordination and create greater barriers to entry (Patlán and Navarrete, 2009). Meanwhile, one of the disadvantages is the damage that is generated when an external agent makes decisions. This is due to the imbalance between the plants that now form one unit.

Finally, vertical acquisitions show as one of its main consequences a change in the market structure (Patlán and Navarrete, 2009) generating a heterogeneous distribution of wealth and unbalanced.

\subsection{Agency theory}

The separation of ownership from shareholders and managers control refers to what it is known today as the agency theory, which is the most dominant among the theories of Strategic Management (VargasHernández, 2005). The generation of a set of rules (rules of the game) within firms, allows to develop rights and obligations of workers and to achieve the most optimal minimization of opportunism within the organization. This is a beneficial result of new forms of governance are implemented within companies (Vargas-Hernández, 2005).

However, it is inherently the presence of conflicts among the members of an agency relationship (principal-agent), since interest between them is not always focused towards a common goal. Thus, while stockholders (pricipals) are focused to achieve a maximization of shareholder value in the long term, managers (agents) can focus more to maximize their own power, income and benefits (Peng, 2010). Asymmetry of information, value-destroying acquisitions, and working consumption executive compensation are examples of agency conflicts.

To control the proliferation of agency problems, shareholders generate major institutional structures through mechanisms such as accountability, transparency and accountability (Vargas-Hernández, 2005) in such a way that there are present agency costs, arising from the cost of monitoring and control to the agents by the principal, the cost of bonding agents for residual waste and non-aligned interest (Peng, 2010).

\subsection{Monopoly}

It is a concession granted by the competent authority to a company to take advantage on an exclusive basis any industry or commerce (Diccionario de la Real Academia Española, 2013). Within the monopoly, the seller can deliver any package of goods or services to a market in hopes of better their quality (Anton y Biglaiser, 2012). Thus, when it is perceived a good quality and having no other alternatives to purchase at a different price, the consumer chooses to access the cash detachment demanded by the only company in the market, despite the increased cost of goods.

In this form, the monopoly generates less consumer surplus, hampers the consumer welfare and further damage crucial in the economy of the middle class, small and medium entrepreneurs and traders who in a forced way should acquire unique goods and services in the market (Castañeda and Rodriguez, 2009).

A concentration almost absolute of power in one or few actors who share the idea to preserve at any cost is the prospect of monopoly displayed by Castaneda and Rodriguez (2009). These analysts suggest a thorough analysis of Article 28 of the Mexican Constitution which states that: In the United Mexican States is prohibited the monopolies, therefore, the law severely punish any concentration or hoarding on one or a few hands of essential consumer goods (Constitución Política de los Estados Unidos Mexicanos, 2013). This is due to the negative effects that have been identified by the loss of welfare through monopolies (Yoon, 2004). 


\section{Fomento Economico Mexicano SA (FEMSA)}

Fomento Economico Mexicano S. A. (FEMSA, 2013) is a company that manufactures and markets consumer products. It began operations in 1890 and throughout its career FEMSA has shown solid growth and an efficient performance. So that currently it is consolidated into four business units: Coca-Cola FEMSA, FEMSA Comercio, Strategic Procurement (Material Packaging and Logistics) and accounts for $20 \%$ of the shares of the Heineken group.

FEMSA has a presence in 9 countries, which are made up of Argentina, Brazil, Nicaragua, Costa Rica, Panama, Colombia, Philippines (newest merger, incorporated in January 2013) and Venezuela. Regarding the industries in which FEMSA has entered as part of its business strategy besides carbonated drinks can be considered as the main marketing activity, are Non-carbonated drinks (Jugos del Valle, Matte Leao, and Brisa bottled water), the dairy Industry (REMIL), packaging materials, distribution and logistics, beer and pharmacies.

Figure 1. FEMSA presence

Source: FEMSA (2013)

With respect to growth of FEMSA within Mexican national framework from January 2011 began a series of mergers in the soft drink industry that caused it increasingly less the amount of bottling Coca-Cola system (Terra, 2013) so that by January 2013, they go from being 13 to 8 bottling Coca-Cola system. FEMSA (the case study) has merged with Grupo Tampico, Cimsa, Queretano Development, Yoli Group and regarding no carbonated drinks Jugos del Valle, thus having $57 \%$ stake in Coca-Cola system in Mexico, as well as being the largest public bottler of Coca-Cola products in the world in terms of sales (FEMSA, 2013).

\section{Contextual framework}

The analysis will favor to show whether or not an effect directly is related to increased welfare of workers in FEMSA regarding geographic and product diversification. It also is showing itself to dimension to the activities of FEMSA related expansion in 2012, the first quarter of 2013 and the short-term projections already that are covered by the company. Likewise, economic indicators will be contemplated at the end of 2012 as well as experiences of employees and former employees of Coca-Cola FEMSA, plant Morelia.

\section{Research methods}

The research undertaken was qualitative, since it is performed data analysis both of the Mexican economy 
and the expansion that has now presented FEMSA. Additionally, a series of interviews with current and former employees of Coca-Cola FEMSA plant Morelia, with the intent to identify and assess the economic and personal well-being of mind to work (agents). Therefore, the variables of this study, are defined as follows:

A. Independent variable: The growth from FEMSA presents strategies such as geographic and product diversification.

B. Dependent Variable: The increased personal and economic well-being of staff working in FEMSA.

Analytical studies were conducted focused on the economic indicators of the country with the intention of showing the current situation in the quality of life of the population, identifying those that at the simple view show advancing of very positive impact on the nation. However, if they are not properly observed, could be consistently incurring in a serious error to consider that the Mexican population actually moves favorably on a greater social economy when actually the opposite is true. Such it is in the case of GDP per capita, which actually shows growth or decline but only in production of goods and services from businesses regardless of income distribution. It is essential to identify the real benefit of the population and therefore, to cover part of the present objective.

With respect to FEMSA growth analysis, it is generated a compilation of information which clearly identified the geographical and product diversification that FEMSA has shown within the previously defined conceptual framework. It is done in such a way as to show any growth dimensions FEMSA has reached in recent years as well as its short-term planning in favor of continuing its growth.

Interviews were conducted with current and former employees of Coca-Cola FEMSA Morelia plant with the intention of identifying a more accurate and objective agency problems to which both the company (principal) and workers (agents) have had face. Thus, the principal-agent relationship continue taking place despite minimizing the effects of personal well-being generated due to this ambitious and challenging objectives FEMSA has proposed throughout its participation in the Mexican market with the intention to remain a highly competitive business.

Conducting interviews with current and former employees should not be considered as a casual situation. However, the cause of having established this frame was to reach to visualize if there are differences in the appreciation of both workers and former welfare workers perceived for them. In the case of the former employees, they could give a fuller appreciation since they have a clear perspective regarding the improvement or not for their welfare while worked for FEMSA compared to their experiences after they have left the company. It is important to highlight that the interviewed former workers left the company by choice, not considered themselves for the sample of respondents with the recessions of contracts cases as that would bias an overview of information and analysis from two viewpoints different than for purposes of present study it is not convenient to mix.

\section{Results}

When analyzing growth contrast between FEMSA and Country Economic indicators, it identifies that FEMSA growth indicators regarding the country economic indicators do not show a positive impact on the current socio-economic welfare of their workers. FEMSA continues to diversify in both vertical and horizontal forms inside and outside of its home country. Its recent acquisitions in January and May 2013 was relating to the business unit of FEMSA Commerce. Now FEMSA focuses on the pharmaceutical industry, which can be seen the presence of a monopoly, because when looking increasingly to integrate a great number of industries, there will be fewer competitors and accumulation of wealth in the same hands.

The units recorded at the end of 2012 in current prices and national currency for the Gross Domestic Product (GDP), are of $134,949.769$ (Fondo Monetario Internacional, 2013), a variation of $6.66 \%$ in favor compared to 2011. Meanwhile, the percentage change in the inflation recorded at the end of 2012 was $4.11 \%$ (Fondo Monetario Internacional, 2013). As noted, the GDP growth rate in 2012 is higher than the inflation in 
2012 so that what must be, from a macroeconomic approach, would see an increase in wages not less than inflation, however, the increase in wages for 2013 was only 3.9\% (Comisión Nacional de los Salarios Mínimos, 2012).

Finally, regarding the National Consumer Price Index (Índice Nacional de Precios al Consumidor, INPC) as of April 2013 compared with April 2012, according to data from Instituto Nacional de Estadística y Geografía (2013) has shown an increase of $4.65 \%$, which puts in manifesto that paid personnel by FEMSA for purposes of this research has not shown an improvement in their quality of life. Further, according to the figures of FEMSA showing growth during the last five years, it could be inferred that the concentration of wealth in Mexico is not still right for increased citizen welfare.

FEMSA, an organization that belongs to the Mexican private sector and has important contributions to national GDP exhibits in its statements of results that earnings are higher year after year. However, expectations of economic development continue to decline and the level of life of the Mexican population do not shows any significant improvement.

Conducted interviews were quite accurate in its results. It was very clear that the principal-agent relationship in Coca-Cola FEMSA is burdensome for operators and a major challenge for the principal. The staff personnel currently working for the company FEMSA describes several similar agency problems, among which are:

A. Salaries and wages are unsuitable or balanced with the workload.

B. Profit sharing is inconsistent with respect to the total income reported by the company.

C. Unbalanced workloads.

D. Asymmetry of information between managers and subordinates.

E. High rate of staff personnel turnover.

F. Little fairness in staff promotion processes.

Workers in Coca-Cola FEMSA plant Morelia generally perceive no improvement in their welfare. They are immersed in a work routine that helps them to meet their needs. Also, the strategies that the company has considered to continue its diversification generate significant dissatisfaction in its staff.

The former workers interviewed report an improvement in their welfare once they made the decision to leave FEMSA, which although does not mean that currently receive a higher income, they have provided evidence that there is a great difference between the agency problems that have subsequent faced in Principal-Agent relationships compared to those experienced in FEMSA. The work under labor pressure, not respecting the workday, inconsistency in information and payment regarding unbalanced workloads, are conditions experienced in FEMSA and subsequently presented a pro improving the quality of life for former FEMSA workers.

\section{Conclusion}

Mexican companies have great potential to develop successful strategies for expansion and diversification. Thus, that they can satisfy an international market with goods and / or services of high quality, a clear example is FEMSA. Currently it has presence in 9 countries. However, the welfare being perceived by the company FEMSA regarding increase in profits year after year is not reflected in their workers. Agency problems are obvious and widespread with greater impact on those concerning the economic well-being. Thus, the assumption of this investigation is met.

It is absolutely necessary the relevance, objectivity and authority not colluding to open the doors to the development of markets that enable competition, providing more control and restrictions on the generation of state monopolies and oligopolies. Finally, private corporatism when there exists tends to impose rules, violate consumer rights and / or agents and impoverish the population (Castañeda and Rodriguez, 2009).

In Mexico it is becoming more important and need the display to achieve a concentration of wealth with greater balance and therefore REAL growth of the national economy. 


\section{References}

Anton, J.J. y Biglaiser G. (2012). Quality, upgrades and equilibrium in a dynamic market. Journal of EconomicTheory. 148 (2013) 1179-1212.

Brocas, I. (2002). Vertical Integration and incentives to innovate. Columbia University, Department of Economics, 420 West 118th Street, New York, NY 10027, USA. 1-32.

Castañeda, J.G, y Rodríguez, M. W. (2009). ¿Y México Por qué no? México: Centzontle. recuperado de http://www.letraslibres.com/revista/libros/y-mexico-por-que-no-de-jorge-g-castaneda-y-manuel-rodriguez

Comisión Nacional de los Salarios Mínimos. (2013). Salarios Mínimos Vigentes a partir del 1 de enero de 2013. Recuperado de

http://www.conasami.gob.mx/pdf/tabla_salarios_minimos/2013/01_01_2013.pdf

Constitución Política de los Estados Unidos Mexicanos. (2013). Artículo 27 constitucional. Recuperado de http://www.diputados.gob.mx/LeyesBiblio/pdf/1.pdf

Diccionario de la Real Academia Española. (2013). Definición de Monopolio. Recuperado de http:/llema.rae.es /drae/?val=monopolio

FEMSA (2009). Informe Anual. Recuperado de

http://www.femsa.com/es/assets/009/18871.pdf

FEMSA. (2013). Quienes Somos. Recuperado de http://www.femsa.com/es/about/

FEMSA. (2013). Presencia FEMSA, obtenida el 03 de junio de 2013. Recuperada de http://www.femsa.com les/about/locations.htm

Fondo Monetario Internacional (Abril, 2013). Datos Estadísticos. Recuperado de http://www.imf.org/external/pubs/tt/weo /2013/01/weodata/weorept.aspx?sy=2002\&ey=2013\&scsm=1\&ssd=1\&sort=country\&ds=.\&br=1\&c=273\&s=NGDP \%2CNGDP_D\%2CNGDPPC\%2CNID_NGDP\%2CPCPI\%2CPCPIPCH\&grp=0\&a=\&pr1.x=62\&pr1.y=10

Hamilton, J. L. (2003)

Hamilton, J.L. y Lee S. B. (1986). The Paradox of Vertical Integration. Southern Economic Journal. Jul86, Vol. 53 Issue 1. Instituto Nacional de Estadística y Geografía (2013). Índices de Precios al Consumidor. Recuperado de

http://www.inegi.org.mx/sistemas/IndicePrecios/Cuadro.aspx?nc=CA55\&T=Índices de Precios al Consumidor\&ST =Índice Nacional de Precios al Consumidor y sus componentes

Patlán, J.P. y Navarrete D.M.Z. (2009). La integración vertical como factor de competitividad en la industria textil y del vestido en México. Universidad Autónoma del estado de Hidalgo. 1-16.

Peng, M. W. (2010). Global Strategy. Cincinnati: Thomson South-Western.

Terra, (2013). Coca-Cola FEMSA y Arca Continental, la guerra por las embotelladoras. Recuperado de http://economia.terra.com.mx/noticias/noticia.aspx?idNoticia=201301211313_REF_81934293

Vargas-Hernández, J.G. (2005). Análisis de Fundamentos de la Teoría Institucional. Révista Digital Universitaria. Vol.6, No.8 ISSN: 1607 - 6079. Recuperado de http://www.revista.unam.mx/vol.6/num8/art84/art84-3.htm

Yoon, S., (2004). Welfare losses due to monopoly: Korea's case. Journal of Policy Modeling. 26 (2004) 945-957.

Young, D.P.T. (1996). Dominant firms, price leadership and the measurement of monopoly welfare losses. International Journal of Industrial Organization. School of Economic Studies, University of Manchester, MI3 9PL UK. 1-13. 